\title{
KONIEC PEWNEJ UTOPII, CZYLI O WSPÓ LCZESNEJ SYTUACJI UKRAIŃCÓW NA WARMII I MAZURACH
}

$\mathrm{R}$ ecenzowana praca jest pierwszą socjologiczną monografią książkową dotyczącą mniejszości ukraińskiej mieszkającej na obszarze Warmii i Mazur. Nie oznacza to, że wcześniej nie było prac dotyczących wyłącznie tej mniejszości na tym obszarze. Warto wymienić osobną pozycję książkową A. Korzeniewskiej-Lasoty, Ukraińcy na Warmii i Mazurach w latach 1947-1970 (Olsztyn 2007), ale jest to praca wyraźnie mająca na celu odtworzenie dziejów Ukraińców w oznaczonym w tytule okresie, a nie rozprawa socjologiczna. Pozostate prace na ten temat albo dotyczą pewnych aspektów życia Ukraińców na Warmii i Mazurach (np. J. Moskałyk, Kościół greckokatolicki na Warmii i Mazurach, w: Tożsamość kulturowa społeczeństwa Warmii i Mazur, pod red. B. Domagały i A. Saksona, Olsztyn 1998), albo są to artykuły dość ogólne, niemające ambicji bycia pełną monografią, w szczególności socjologiczną (np. M. Panius, Ukraińcy na Warmii i Mazurach, w: W cieniu akcji „Wista". Ukraińcy we współczesnej Polsce, pod red. M. Melnyka, Olsztyn 2008).

Recenzowana praca zatem wypełniła dotkliwą luke w badaniach socjologicznych nad mniejszościami narodowymi w Polsce. Warto nadmienić, że jest uwieńczeniem wieloletniej działalności naukowo-badawczej autorki nad tematem określonym w tytule. Wcześniej już ukazywały się drukiem jej artykuły w całości bądź w części dotyczące Ukraińców z Warmii i Mazur, będące poniekąd studiami przygotowawczymi do niniejszej

Bożena Domagała, Ukraińcy na Warmii i Mazurach. Studium procesów asymilacji, edycja wspólna Towarzystwa Naukowego i Ośrodka Badań Naukowych im. Wojciecha Kętrzyńskiego, Olsztyn 2009, ss. 213. 
monografii. Poza tym autorka od wielu lat nie tylko wspiera, ale też inspiruje badania innych, szczególnie osób związanych z jej macierzystym Ośrodkiem Badań Naukowych im. Wojciecha Kętrzyńskiego w Olsztynie. Owocem tej aktywności jest m.in. tom zbiorowy pt. Tożsamość kulturowa społeczeństwa Warmii i Mazur (pod red. B. Domagały i A. Saksona, Olsztyn 1998), w którym część artykułów poświęcono mniejszości ukraińskiej.

Podstawową ideę recenzowanej przeze mnie książki zawiera już jej tytuł, mówiący o procesach asymilacji. Za czasów komunistycznych pojawiały się prace socjologiczne na temat mniejszości narodowych zamieszkujących Polskę, których przewodnim motywem była nawet nie hipoteza, ale dość prosta obserwacja, że mniejszości te przechodziły wtedy proces asymilacji w środowisku polskiej większości (np. A. Kwilecki, Łemkowie. Zagadnienia migracji i asymilacji, Warszawa 1974; K. Pudło, Łemkowie. Proces wrastania w środowisko Dolnego Śląska 1947-1985, Wrocław 1987). W latach 90. socjolodzy często pisali o powrocie do korzeni środowisk mniejszościowych, o inicjatywach dysasymilacyjnych (np. M. Melchior, Społeczna tożsamość jednostki, Warszawa 1990), a w drugiej potowie lat 90. i na początku XXI w. realizowano programy tzW. wieloetniczności w Polsce.

W świetle badań prezentowanych w recenzowanej pracy wiele wskazuje na to, że zarówno te mnogie inicjatywy (niekiedy wspierane przez państwo czy też różne fundacje) i programy na rzecz społeczeństwa wieloetnicznego w Polsce nie przyniosły trwałych rezultatów. Procesów asymilacyjnych nie udało się zatrzymać, a tym bardziej -- odwrócić. Oczywiście trzeba tę diagnozę traktować, jak to zazwyczaj jest w naukach humanistycznych, jako hipotezę, ale na tyle dobrze udokumentowaną, że przynajmniej warto się nad nią zastanowić. Sama autorka zadaje sobie pytanie: „czy zdominowane i zmarginalizowane mniejszości mogą zmienić swój status i wykorzystać możliwości, jakie otwiera przed nimi realizowana przez państwo polityka wielokulturowości?" (s. 37). Wydaje się, że możliwości wykorzystać można i należy, ale czy prowadzi to do owej zmiany statusu?

Autorka przeprowadziła badania w obrębie trzech wymiarów trwania grupy etnicznej: języka, religii i pamięci historycznej. Z deklaracji B. Domagały wynika, że „badania łączą perspektywę socjologiczną z antropologiczną, ujęcia ilościowe z jakościowymi, spojrzenie diachroniczne z synchronicznym" (s. 20). Wstępne badania ankietowe potraktowane zostały przez autorkę jako pilotażowe (w 2005 r. w Bartoszycach, Olsztynie, Pasłęku). Odpowiednio do zamierzenia badawczego ankieta dotyczyła sposobu funkcjonowania języka ukraińskiego, praktykowania religii greckokatolickiej, strategii zachowania etniczności i więzi z terytorium. Badania te "miały charakter diagnostyczny" (tamże). W kolejnym etapie badań (typu jakościowego) w 2006 r. przeprowadzono 15 wywiadów z nauczycielami języka ukraińskiego (m.in. w Braniewie, Elblągu, Giżycku, Kętrzynie, Kruklankach, Węgorzewie). Pytano respondentów o znajomość języka ukraińskiego wśród dzieci, o cele, jakie stawiają sobie nauczyciele i rodzice, o związek między znajomością języka a trwaniem grupy etnicznej, o zasięg i przejawy asymilacji. W kolejnym etapie badań (2007-2008) przeprowadzono 14 wywiadów swobodnych z księżmi greckokatolickimi, m.in. w parafiach w Bartoszycach, Górowie Itawieckim, Lidzbarku Warmińskim, Olsztynie, Braniewie, Elblągu, Morągu, Giżycku, Kętrzynie, Węgorzewie). Pytano o rolę społeczno-kulturalną parafii greckokatolickiej, rolę religii jako wartości kultury narodowej i jako osi tożsamościowej, o zmiany wyznania i małżeństwa mieszane, laicyzację, etnicyzację Kościoła greckokatolickiego. Przy okazji tych badań przeprowadzono obserwacje w parafiach w Bartoszycach i ltawie. Ponadto autorka zanalizowała wywiady swobodne prowadzone w latach 1996-1997 w Ośrodku Badań Naukowych w Olsztynie z Ukraińcami mieszkającymi m.in. w Górowie Itawieckim, Kętrzynie, Węgorzewie, Wydminach. Pytano o sytuację respon- 
dentów po 1947 r. i doświadczenia przerwania ciągłości życia kulturowego i religijnego, kształtowanie się zasad współżycia z innymi, konflikty etniczne, o temat ciągłości i zmiany elementów tożsamości takich, jak język, religia, pamięć (przed i po przesiedleniu), o małżeństwa mieszane. Wykorzystanie tych ostatnich badań pozwoliło na poznanie perspektywy zmian w dłuższym czasie.

Jakkolwiek autorka podjęła znaczny wysiłek, aby dogłębnie zbadać procesy funkcjonowania języka, religii i pamięci historycznej w środowisku ukraińskim na Mazurach i Warmii, zabrakło wśród jej respondentów osób pochodzących z niższych grup społeczności ukraińskiej, np. zwykłych robotników rolnych dawniej pracujących w PGR-ach, czy też mających swe gospodarstwa rolne na wsiach mazurskich, robotników mieszkających w Olsztynie czy Elblągu. Autorka skupiła się bowiem na badaniu przedstawicieli jeśli nie elity, to w każdym razie "przodowników” w rozumieniu F. Znanieckiego (nauczyciele, księża). To powoduje, że badacz otrzymuje dość charakterystyczny materiał badawczy (przemyślany i ideologiczny). Chociaż oczywiście biorąc pod uwagę cel pracy (przypomnijmy: badania w obrębie trzech wymiarów trwania grupy etnicznej - w wymiarze języka, religii i pamięci historycznej), można znaleźć uzasadnienie dla skupienia się na tych właśnie respondentach.

Według autorki perspektywę asymilacji mniejszości uprawdopodobnia postać transformacji w Polsce. Wprawdzie dzięki niej mniejszości uzyskały pewne możliwości rozwoju, zorganizowania się, a nawet dofinansowania konkretnych działań, jednocześnie jednak w ramach transformacji „o pozycji życiowej jednostki decyduje kapitał ekonomiczny, a inne typy kapitałów, np. kapitał społeczny czy kulturowy tracą na znaczeniu bądź mogą to znaczenie utrzymać pod warunkiem rekonwersji w kapitał ekonomiczny" (s. 39) W rezultacie „wartości grup mniejszościowych pozostają ważne dla stosunkowo wąskich grup społecznych" (tamże). Kolejnym czynnikiem, który może przyczynić się do asymilacji, jest „narastający indywidualizm". Polega on na postawie, aby „zmagać się z losem, licząc przede wszystkim na własne siły. Nie ma tu miejsca na wspólnoty, a jeżeli pojawiają się one w przestrzeni zainteresowania, to traktowane instrumentalnie jako narzędzie do osiągania własnych celów" (tak pisze autorka, relacjonując artykuł H. Domańskiego i A. Dukaczewskiej, Orientacje indywidualistyczne w Polsce, „Kultura i Społeczeństwo” 1994, nr 4, s. 61-82). Innym procesem sprzyjającym asymilacji jest globalizacja, w ramach której pojęcie ojczyzny „traci swój potencjał i swoją atrakcyjność. (...) Wszystko odbywa się w przestrzeni bez właściwości, w której uniwersalne symbole, wzory i sposoby konsumpcji stwarzają o wiele większe możliwości, by upodobnić się do większości (...), a kłopotliwą przeszłość zamienić na wspólną dla wszystkich przyszłość" (s. 40) - konkluduje autorka w duchu H. Bausingera, Sensless Identity, w: Identity: Personal and Socio-Cultural, Uppsala 1983, s. 337-346. Zatem detradycjonalizacja, desakralizacja i indywidualizacja idą tu w parze z silnym oddziaływaniem kultury masowej.

W językowym wymiarze trwania grupy mniejszościowej Ukraińców na Warmii i Mazurach najważniejszym elementem sytuacji językowej jest to, że dotychczas w diasporze używany był nie literacki język ukraiński, ale szeroka gama dialektów, a nawet wioskowych narzeczy „przywiezionych” po przesiedleniu w 1947 r. ${ }^{1}$ Z oczywistych powodów dialekty te nie dawały i nie dają ich użytkownikom pełnych możliwości funkcjonowania językowego we współczesnym świecie, m.in. z powodu braku wyrazów oznaczających wiele pojęć już to abstrakcyjnych, już to związanych z procesami modernizacji. Powodo-

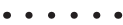

Ukraińcy na Warmii i Mazurach przesiedleni w ramach akcji „Wisła” pochodzą z różnych obszarów etnograficznych, takich jak: Chełmszczyzna -- 19,2 tys., Nadsanie -- 15,8 tys., Bojkowszczyzna -- 14,5 tys., Podlasie Płd. -- 6,8 tys., Łemkowszczyzna -- 0,3 tys., za: E. Misito, Akcja „Wisła” Dokumenty, Warszawa 1993, s. 447. 
wało to i nadal powoduje adaptowanie wielu słów z języka polskiego. Dodajmy do tego małżeństwa, wprawdzie obustronnie ukraińskie, lecz osób pochodzących z różnych obszarów dialektalnych, a otrzymamy pełny obraz języka, jakim posługują się w życiu codziennym Ukraińcy z badanego obszaru. Ten właśnie język był i jest w wielu wypadkach nadal używany nawykowo, bezrefleksyjnie -- jako coś oczywistego. Dzieci wywodzące się z takiej właśnie sytuacji językowej w szkołach i punktach nauczania języka ukraińskiego są uczone oczywiście języka literackiego. Posługują się nim po to, by być odbiorcami komunikatów, które „w sferze historii i kultury tworzą treści składające się na współczesną ideologię narodową, budujące i podtrzymujące więź ideologiczną z narodem ukraińskim. (...) Zinstytucjonalizowana transmisja ze szczególnym uwzględnieniem szkolnej skutecznie wykorzenia kulturę etniczną z jej naturalnego kontekstu, a mianowicie z kontekstu życia codziennego mniejszości. Kultura ta w tym także język, staje się pewną abstrakcją (...) który przestaje być elementem ich bliskiej codzienności. Tym też można tłumaczyć fakt, iż język ukraiński przestaje być językiem codziennej, nawykowej komunikacji uczniów szkół ukraińskich" (s. 67). Uczniowie między sobą zaczynają mówić w języku polskim, który jest im nieporównywalnie lepiej znany niż ukraiński (szczególnie w standardzie literackim). Na te procesy zwracają uwagę nauczyciele języka ukraińskiego. Szkolnictwo mniejszościowe, zamiast podtrzymywać codzienne używanie języka ukraińskiego, okazuje się tu „przeciwskuteczne”. Jak pisze autorka, "Celem szkół mniejszościowych staje się mobilizacja świadomości etnicznej uczniów” (s. 68), a to właśnie, jak pisze, „zmniejsza pole więzi nawykowej a poszerza obszar więzi ideologicznej" (s. 48). Sami nauczyciele stwierdzają, że gdy element spotkania i zabawy dzieci zaczyna przeważać, "dzieci rozmawiają ze sobą po polsku, nawet te, które umieją po ukraińsku" (s. 72). Lekcje są w końcu też spotkaniem z takimi dziećmi, które pochodzą z małżeństw mieszanych lub nawet obustronnie ukraińskich, w których się jednak nie mówi po ukraińsku na co dzień. Zatem wspólnym językiem staje się dla nich język polski. Sami rodzice traktują nauczanie ukraińskiego jako okazję do tego, aby dzieci były razem w grupie rówieśniczej, a samą naukę -- nie jak spotkanie z kulturą ojczystą (ideologicznie), ale jak opanowanie jeszcze jednego języka obcego, którego znajomość może się przydać.

Literacki język ukraiński jako język domowy prawie w ogóle nie jest używany, a „W większości domów używa się języka polskiego” (s. 86); "sądzę - stwierdza jeden z respondentów -- że język ukraiński jest używany na co dzień przez pokolenia dziadków i babć” (s. 87). Jeden z nauczycieli stwierdził: „możliwości są, próby się podejmuje, ale asymilacja jest szybsza gdzieś o 50\%" (s. 87). A pamiętać trzeba, że dzieci uczące się w szkołach ukraińskich i punktach nauczania języka, to tylko niewielka grupa dzieci żyjących w badanym środowisku i to niepochodząca z najniższych warstw społecznych. Jak echo wraca tu postulat, aby właśnie warmińsko-mazurskich Ukraińców z tych warstw socjologicznie zbadać.

Autorka uważa, że zależność między wyznawaną religią a trwaniem wspólnoty etnicznej jest wtedy znacząca, "gdy wyznanie jest częścią tożsamości etnicznej, wówczas manifestowanie tego wyznania staje się cechą dystynktywną grupy etnicznej wykorzystywaną dla jej wzmocnienia i przeciwstawienia się innym grupom" (s. 135). Dla Ukraińców w Polsce taki charakter ma wyłącznie Kościół greckokatolicki. W religijnym wymiarze trwania grupy Ukraińców, których badała autorka, ważne jest to, że nie byli oni przed przesiedleniami wyznawcami wyłącznie chrześcijaństwa w obrządku greckokatolickim (Łemkowszczyzna, Bojkowszczyzna, Nadsanie, w części Chełmszczyzna), ale też prawosławia (Podlasie, w części Chełmszczyzna). Oczywiście, po przesiedleniu duża część Ukraińców 
zaczęła praktykować w Kościele rzymskokatolickim, bo takie postępowanie było preferowane przez polską większość, a cerkwi przecież prawie nie było. Jest to ważne dlatego, że religia rzeczywiście podtrzymuje trwanie narodu, ale wtedy wyznaje on jedną religię, a nie wiele (i to jeszcze niezbyt dobrze się nawzajem tolerujących!). Świadomie działa na rzecz trwania narodowego Ukraińców w Polsce tylko Kościół greckokatolicki (na badanym obszarze 12-13 tys.). Na badaniu wypowiedzi księży z tego Kościoła autorka się skupiła. Według respondentów dynamika rozwoju grekokatolicyzmu na badanym obszarze po okresie lat 90. i początku XXI w., kiedy powstało 10 nowych parafii i wybudowano 6 nowych cerkwi, proces ten właściwie się zakończył. Wierni tego Kościoła zdaniem respondentów traktują praktyki religijne w tym Kościele w charakterystyczny sposób: „Badania pokazują, iż w wielu greckokatolickich rodzinach praktykuje się zwyczaj, iż do pobliskiego kościoła chodzi się w niedzielę, a do oddalonej o kilka czy kilkanaście kilometrów cerkwi jedzie się w większe święta" (s. 129-130). Zatem co tydzień w niedzielę wyznawcy grekokatolicyzmu są obecni w kościele rzymskokatolickim, a tylko w święta i uroczystości rodzinne w cerkwi. To też świadczy o innym stosunku badanych do tych obrządków. To jest tak, jakby zwyczajnym obrządkiem było rzymskokatolicki, a nadzwyczajnym greckokatolicki. Obserwacje księży potwierdzają w tej kwestii wywiady z osobami świeckimi.

Kondycja grekokatolicyzmu na badanym obszarze jest też uzależniona od zjawisk migracyjnych („Młodzież wyjeżdża na studia i już nie wraca. Ludzie wyjeżdżają też za granicę", s. 132) oraz coraz słabszych kompetencji językowych wiernych. Powoli wchodzi do użycia język polski („Język polski już wchodzi na weselach i pogrzebach, gdy się spotykają Polacy i Ukraińcy. Na weselach na przykład zdarza się homilie są po polsku, a gdy są małżeństwa mieszane to polska strona przysięga po polsku", s. 142). Księża greckokatoliccy stoją, jak sami wskazują, w perspektywie 20 lat przed problemem przejścia w obrzędach na język polski („Kiedyś może się tak stać, że w miejsce ukraińskiego wejdzie język polski", tamże).

Biorąc to wszystko pod uwage, można stwierdzić, że praktykowanie w Kościele greckokatolickim chyba w największym stopniu przyczynia się do trwania tożsamości ukraińskiej w badanej grupie. Mogą świadczyć o tym statystyki narodowościowe ze spisów powszechnych, które liczbę Ukraińców na badanym obszarze określają na około 16 tys., a mniej więcej tylu jest tu grekokatolików.

W badaniu pamięci o przeszłości jako wymiarze trwania grupy mniejszościowej autorka skupiła się na funkcjonowaniu stereotypu Ukraińca-bandyty w środowisku badanych. Chodzi o pytanie, w jaki sposób ten stereotyp, którego źródłem, a częściowo nośnikiem do dziś jest z pewnością strona polska, jest wykorzystywany w celach budowy własnej tożsamości przez samych Ukraińców. Polacy są nośnikiem tego stereotypu w coraz mniejszym stopniu chociażby z tego powodu, że właściwie nie ma lub prawie nie ma tych pokoleń, które pamiętałyby z własnego doświadczenia życiowego najostrzejsze formy konfliktów polsko-ukraińskich z czasów II wojny światowej. Warto też zaznaczyć, że na obszarze Warmii i Mazur przesiedleńcy z Wołynia i okolic Lwowa osiedlali się w minimalnym stopniu. Na ten obszar przesiedliły się raczej osoby z pogranicza polsko-białoruskolitewskiego, które nie miały w czasie wojny kontaktów z Ukraińcami. Przytaczając badania W. Łukowskiego², pokazujące powolny zanik negatywnego stereotypu Ukraińca, autorka stwierdza, że „cechy współtworzące pozytywny wizerunek Ukraińca w świadomości mieszkańców Mazur trzeba raczej przypisać doświadczeniom życia codziennego na Mazurach" (s. 169). Stereotyp ten nawet jeśli jest negatywny, to opiera się na zupełnie nowych

- •. •

2 W. Łukowski, Spoteczne tworzenie ojczyzn, Warszawa 2002 
podstawach: „Ukraińcy kojarzą się z przemytem, nielegalną pracą w Polsce i przestępczością" (s. 170). Ten obraz wypiera obraz konfliktów na Wołyniu z lat wojny. Natomiast sami Ukraińcy, których autorka badała, nadal widzą ten stereotyp w formach tradycyjnych. Zazwyczaj podkreślają swoją niewiare w jakiekolwiek mordy dokonywane szczególnie przez UPA na Polakach w czasie wojny. Uważają te informacje za medialne kłamstwa.

Za A.D. Smithem³ autorka widzi budowanie tożsamości narodowej Ukraińców warmińsko-mazurskich na bazie ideologii nacjonalistycznej, co potwierdzają jej zdaniem badania wśród Ukraińców przeprowadzone przez Bożenę Bebę w Ośrodku Badań Naukowych w Olsztynie w latach 1994-1995. Na pytanie: „Czy Pan(i) uważa, że południowo-wschodnie ziemie Polski, tak zwany Zakierzoński Kraj, powinny być w przyszłości włączone w skład Ukrainy?", twierdząco odpowiedziało 31 osób, przecząco 19, pozostałe 13 osób nie udzieliło odpowiedzi. Jeszcze wyraźniej widać to w pytaniu o stosunek do OUN-UPA: 44 osoby wyraziły pozytywny stosunek do tych organizacji, 2 osoby stosunek ambiwalentny, a pozostali badani (17 osób) nie odpowiedzieli na pytanie.

Temat ten znalazł też swoje miejsce $w$ badaniach autorki. Na przykład same mordy na Polakach prawie nie były przez respondentów wspominane, a jeżeli tak, to osoby badane wątpiły w prawdziwość tych faktów, szczególnie wtedy gdy oskarżano o to UPA. W jednym z wywiadów znalazły się słowa kuriozalne: „Wcześniej od 1943 roku Ukraińcy masowo mordowali Polaków. To była gorzka pigułka dla Polaków i trudno ją przełknąć, ale czy to znaczy, że mamy ciągle podtrzymywać stereotyp formowany przez 60 lat. Ciągle trudno jest wypowiedzieć w Polsce prawdę, że Ukraińcy byli ofiarami Polaków i różnych formacji polskich" (s. 188). Tę wypowiedź trudno jest skomentować i autorka żadnego komentarza nie podała. Wypowiedzi respondentów zdają się świadczyć o tym, że informacje zarówno o stereotypach Ukraińców, jak i o dawnych konfliktach polsko-ukraińskich na kresach czerpią oni z mediów, ze szkoły i z opracowań historycznych, natomiast swoje krzywdy znają z pamięci biograficznej, przekazu rodzinnego -- a to jest zasadnicza różnica, jeśli chodzi o samo społeczne funkcjonowanie tych „śladów pamięciowych" W stosunkach z Polakami. Jak pisze autorka: „Tak rozumiana pamięć jest nie tylko barierą asymilacji, ale także barierą polsko-ukraińskiego pojednania" (s. 190). Dyskurs na temat pamięci historycznej jest rzeczywiście dyskursem zideologizowanym, ale dyskurs ten tworzony jest ze strony Ukraińców przede wszystkim przez przedstawicieli elity ukraińskiej i propagowany przez środowiska, z których bezpośrednio wywodzą się respondenci. W badaniach autorki musiało zatem ukazać się takie właśnie oblicze tego dyskursu (sądzę, że prawdziwe), skoro badała akurat te środowiska, które ów dyskurs w takim akurat kształcie tworzą.

Recenzowana książka zaopatrzona jest w obszerną (choć niewyczerpującą) bibliografię tematu. Jest napisana przejrzyście, bez emocjonalnego podejścia. Autorka nie unika tematów trudnych i kontrowersyjnych, i czyni to rzetelnie, nie popadając w mielizny wartościowania. Treść książki nie pozostawia czytelnika obojętnym i to chyba jest wielkie zwycięstwo autorki.

JERZY ŻURKO

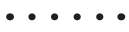

3 A.D. Smith, Theories of Nationalism, London 1971. 